\title{
Analysis of the Effectiveness of Learning in the Use of Learning Modules Against Student Learning Outcomes
}

\author{
Rika Rahmawati $1{ }^{1}$, Fitria Lestari ${ }^{2}$, Rofiqul Umam ${ }^{3}$ \\ 1Universitas Islam Negeri Raden Intan Bandar Lampung, Indonesia \\ 2Universitas Muhammadiyah Lampung, Indonesia \\ ${ }^{3}$ School of Science and Technology, Kwansei Gakuin University, Japan \\ * Corresponding Author. E-mail: rrahmawati850@gmail.com
}

\begin{abstract}
Abstrak
Saat ini masih ada siswa yang mengalami kesulitan dalam belajar, disebabkan karena keterbatasan sumber belajar. Salah satu upaya yang dapat dilakukan adalah penggunaan modul dalam pembelajaran. Modul adalah bahan ajar cetak yang dirancang untuk dapat dipelajari secara mandiri oleh peserta pembelajaran. Penelitian ini bertujuan untuk mengetahui pengaruh penggunaan modul terhadap hasil belajar siswa Mts Hasanuddin. Melalui analisis perbedaan ratarata hasil belajar matematika antara yang menggunakan modul dan yang tidak menggunakan modul.Metode yang akan digunakan dalam penelitian ini adalah eksperimen dengan tingkat eksplorasi kuantitatif. Adapun teknik pengumpulan data pokok menggunakan teknik tes yaitu untuk mengetahui hasil belajar siswa. Pengujian hipotesis dengan menggunakan rumus statistik t-tes. Berdasarkan hasil pengujian hipotesis disimpulkan rata-rata hasil belajar matematika siswa yang menggunakan modul lebih tinggi dari siswa yang tidak menggunakan modul.
\end{abstract}

Kata kunci: Hasil belajar, Modul belajar

\begin{abstract}
At present there are still students who have difficulty in learning, due to limited learning resources. One effort that can be done is the use of modules in learning. Modules are printed teaching materials designed to be studied independently by learning participants. This study aims to determine the effect of the use of modules on the learning outcomes of students in MTs Hasanuddin Teluk Betung. Through the analysis of diffrences in the average of mathematics learning outcomes between those who used modules and those who did not use modules. The method used in this study is experiments with quantitative exploratory levels. The basic data collection technique uses a test technique that is to determine students learning outcomes. Testing hypotheses by using the $t$-test statistical formula. Based on the results of hypothesis testing it was concluded that the average mathematics learning outcomes of students using modules were higher than students who did not use the module.
\end{abstract}

Keywords: Learning outcome, Learning modules

\section{INRODUCTION}

Education plays an important role to improve quality Human Resources (HR) in ensuring the continuity of national development (Mallaherang, Arsyad, \& M, 2018), so that in education there is a learning process that should pay attention to various aspects that support the success of the learning process as stated by Barrington in (Andayani, 2017) in the learning process should consider the characteristics of different students, so that these differences can be accommodated through the selection of appropriate media and learning strategies. One of the competencies that a teacher needs to have in carrying out their duties is by developing teaching materials. The development of teaching materials is important for teachers to make learning more effective, efficient, and not deviating from the competencies they want to 
achieve. The use of teaching materials that are not appropriate in every lesson causes the message delivered by the teacher to be less understood by students. The role of teaching materials will not be seen if its use is not in line with the contents of the learning objectives that have been formulated, if their use is not in accordance with the learning objectives, the teaching materials cannot support a learning process. Without teaching materials it will be very difficult for teachers to improve the effectiveness of learning, as well as students, without teaching materials it will be very difficult to adjust to learning (Setiawan, 2016).

One of the teaching materials that can be used is the module. According to Suprawoto in the Module is a learning tool in written form that is arranged systematically, contains learning material, methods, learning objectives based on basic competencies or indicators of achievement of competencies, instructions for self-learning activities, and provides opportunities for students to test yourself through the exercises presented in the module (Wigati, Maharta, \& Suyatna, 2015). The module is interpreted as a printed learning unit (Erlinda, 2017). Made Wena inside (Abdurrahman, Saregar, \& Umam, 2018) concluded some opinions about the meaning of the module, which he defined as one form of print media that contained a unit of learning, equipped with various components so as to enable students to use them to achieve their goals independently.

Based on some of these opinions, then when combined learning and module understanding, what is meant by learning with modules in this study is a learning activity carried out by students and under the supervision and guidance of the teacher by using the module media to achieve learning objectives more effectively and efficiently (Arslan, 2016). There are several advantages of using modules as individual media, namely: (1) learning can be done by students anytime and anywhere; (2) learning is done step by step (Kusuma, 2017); and (3) students can learn at their own pace. In addition to the advantages of using modules, there are also disadvantages, namely: (1) the module can only be used by students who can already read well; and (2) learning can be effective if students already have an awareness of learning as a process of behavior change because of experience (Kristanto, 2017).

Modules used in learning activities have certain components as one of the characteristics of individual learning, namely: 1) rational, 2) objectives, 3) input tests, 4) learning activities, 5) self-tests, and 6) final test (post test)(Setiawan, 2016).

Sofan Amri and Iif Khoiru Ahmadi (2010: 199) more detailed components in the learning module (Untari, 2017) as follows:

1) Introduction: which contains a general description, such as the material presented, knowledge, skills and attitudes that will be achieved after learning, including initial abilities that must be possessed to study the module;

2) Learning objectives: contains specific learning goals that must be achieved by students, after studying the module. This section also includes terminal objectives and final objectives, as well as conditions for achieving goals;

3) Initial test: which is used to determine the position of the student and know his initial ability, to determine where he should start learning, and whether it is necessary to learn or not the module;

4) Learning experience: which contains detailed material for each specific learning goal, followed by formative assessment as feedback for students 
Desimal, 2 (3), 2019 - 235

Rika Rahmawati, Fitria Lestari, Rofiqul Umam

about the learning objectives achieved;

5) Learning resources: contains learning resources that can be traced and used by students;

6) Final test: the instruments used in the final test are the same as those used in the initial test, only more focused on the terminal objectives of each module.

Learning with modules allows students to learn independently, because in the module students have been given various instructions that make it easier to learn the module and follow the learning activities presented in the module(Putra, 2015). Students understand what activities must be carried out because in the module explained in detail what will be achieved by students, what to do, how to do it, how to know its success, and so forth. So with this module the teacher no longer functions as the only source of learning. Students can learn independently, collaborate, and discuss with each other(Syed, Alvina, \& Amnda, 2017).

The use of modules has been carried out by several previous studies such as those conducted by (ST Aminah Kadang, 2017) the results of his research that the use of modules can improve cognitive abilities and scientific communication, (Rachmad, Ertikanto, \& Suana, 2017; Simamora, Ertikanto, \& Wahyudi, 2017) the results of his research found that the use of modules can improve cognitive and affective learning outcomes,(Nurhayati \& Boisandi, 2015) the use of modules can improve concept mastery.

Based on several studies that have been carried out, in broad outline their results indicate that the module can improve student mathematics learning outcomes, because the module as a learning tool that contains material, methods, exercises, and evaluations that students can use to learn independently(Santi Widyawati, 2016).
Students can also build their own knowledge through a constructivism approach based on previous experience (Oktaviani \& Retnowati, 2017). The involvement of learning outcomes in the learning process is expected that student learning outcomes will be better (Endah Retnowati \& Ayres, 2018).

Student learning outcomes referred to in this study are scores obtained by students from the evaluation results after participating in learning activities using modules, with the following criteria: 1) a score of $73-100$ is categorized as a complete student learning outcomes in mathematics, 2) a score of $0-73$ is categorized as a result of learning mathematics students have not yet finished (E Retnowati, Blegur, \& Retnowati, 2018).

Learning outcomes contain the meaning of students' success in their learning activities, with good learning outcomes is hope and pride for someone. However, failure and success are always present in the lives of students, some are successful in learning satisfactorily and some are failing (Komikesari, 2016). Getting satisfying learning outcomes is not easy, it requires a variety of efforts from the person and those around him. Learning outcomes are not the product of a single effort, or the monopoly of just one factor, but the results of various efforts that are integrally interconnected with each other, each of which has an important role in creating an optimal learning outcome (Endah Retnowati, 2018). One of the factors influencing student learning outcomes is the application of learning to modules. Learning with modules will further enhance student learning outcomes, because of the control of the achievement of learning outcomes through the use of competency standards in each module (Haq, Najmonnisa, \& Saad, 2015).

Based on the explanation above, this study aims to determine the effect of the 
use of modules on student learning outcomes in Mts Hasanuddin. In this study, researchers will analyze the effectiveness of learning by using modules in Mts Hasanuddin.

\section{METHOD}

The method used in this study is an experimental research method with a quantitative exploration level. The experimental research method is a research used to look for the effect of certain treatments(Jolliffe, 2002). The experimental method is seen from the side and its usefulness in accordance with the research the author is doing, namely to test the presence or absence of the influence of the independent variable that is the use of modules on the dependent variable that is the learning outcomes of students' mathematics.

In this study, an analysis of the effectiveness of comparing learning outcomes between using modules and not using modules was carried out. In addition, the research applied is a type of experimental research, by testing the use of modules in class VIII B (experimental class) to analyze whether or not there is an effect on improving student learning outcomes and class VIII C (control class) or not using a learning module. Through this research it is expected can help teachers, especially teachers in mathematics in their efforts to improve student mathematics learning outcomes and can be used as literature in future research

The research instrument in this study used tests in the form of essays. In conducting the test the number of questions given is 10 questions in the form of essays. Giving score of 10 questions in the form of essays with the following details:

1. If students don't give an answer then a grade of 0 (zero) is given
2. Students can write things that are known to the problem then given a score of 3

3. Can write things that are known, asked, and write formulas and answer according to the answers to the questions but there are some answers given wrongly then given a score of 5.

4. Can write things that are known, asked and write formulas and answer according to the answers to the questions but the final answer is wrong then given a score between 8 .

5. By answering with the correct results given a score of 10 .

Thus the maximum score of all questions is 100 , while the minimum score is 0 (zero). So student scores move in intervals of $0<x<100$.

The procedure in this study consisted of several steps, namely:

\section{Preparatory steps}

Before the authors carry out research, the authors do pre-research that aims to determine the condition of schools, students, research officials, and others. After carrying out pre-research, the authors submit a research permit to the head of Mts Hasanuddin. The author makes a research instrument consisting of RPP, Syllabus, Test Question Grid, Question Instrument, and Answer Key. In addition, the authors discuss the implementation of research with the tutor teacher in accordance with the material to be delivered.

\section{Measures of Validity Test and Measurement Test Reliability}

Before the test questions are given to the research sample, the questions are tested for validity and reliability outside the research sample. After each item is valid and reliable, the question can be used.

\section{Research Implementation Steps}

The author conducts learning activities using Modules in class VIII B as an experimental class and learning 
activities using do not use modules in class VIII C as a control class.

\section{Test Implementation Steps}

Knowing the influence that occurs, after the material has been submitted, then a total of ten questions in the form of essays are conducted in the experimental class and the control class with the same questions.

\section{Data Collection Steps}

After conducting research and obtaining the necessary data from the results of research in the experimental class and in the control class, the authors then collected data so that the data needed to conduct data analysis and hypothesis testing was collected.

\section{RESULTS AND DISCUSSION}

Test data normality as a requirement of analysis in testing hypotheses. Path analysis used in this study requires that variable data must be normally distributed or close to normal (Fahrizal \& Wiyanto, 2016). Data normality test, carried out using the Chi Square technique $\left(\chi^{2}\right) \cdot \chi_{\text {hit }}^{2}<\chi_{\text {daf }}^{2}$ for a significant level of $5 \%$ obtained $1.88<7.81$ and for a level of $1 \%$ obtained $1.88<11.30$ so that $\mathrm{H}_{\mathrm{o}}$ is accepted means the data come from populations that are normally distributed. Actually $F_{\text {hit }}<F_{\text {daf }}$ for real level 5\% obtained $1,04<1,74$, and for real level $1 \%$ obtained $1,04<2,21$, means that both data have homogeneous variance.

Testing the truth of the second hypothesis, the authors used a difference test of two averages. The pair of hypotheses are as follows:

$\mathrm{H}_{\mathrm{o}} \quad: \mu_{1} \leq \mu_{2}$

The average learning outcomes of mathematics who use modules are lower or the same as those who do not use modules.

$\mathrm{H}_{\mathrm{a}} \quad: \mu_{1}>\mu_{2}$

The average learning outcomes of mathematics who use modules are higher than those who do not use modules. B previous calculation obtained:

Real level 5\% obtained 4,07 > 1,67 and on real level $1 \%$ obtained $4,07>2,34$. With testing criteria $\mathrm{t}<\mathrm{t}_{(1-\alpha)}$ clearly not fulfilled, so $H_{0}: \mu_{1} \leq \mu_{2}$ rejected. It was concluded that the average mathematics learning outcomes of students who use modules are higher than the average mathematics learning outcomes of students who do not use modules. The use of modules has a positive effect on student mathematics learning outcomes.

Based on the results of research that has been carried out, there is an influence of the use of modules on student mathematics learning outcomes. In the experimental class that uses modules, students can learn according to their own methods and techniques, giving opportunities for students to correct mistakes(Erlinda, 2017).

Research conducted by the author obtained data analysis in the form of the results of each student's score and the average value obtained by students, based on the results of the study in MTs of Hasanuddin from 38 students found in class VIII B as an experimental class the highest scores achieved by students are 100 , while the lowest score obtained by students is 30 . While of the 35 students found in class VIIIC as the control class, the highest value achieved by students is 85 , while the lowest score obtained by students is 20 .

The results of the data analysis and calculations performed, the normality test results obtained showed that the sample came from populations that were normally distributed, because at a significant level of 5\% it was evident that $\chi_{\text {hit }}^{2}<\chi_{(1-\alpha)(k-3)}^{2}$, for the experimental class obtained $1,42<7,81$ and for the control class obtained $1,88<7,81$. This shows that both classes are normally distributed.

Difference in the average test obtained by the calculation of the 
experimental class group and the control class, it turns out $\mathrm{t}$ hit $>\mathrm{t}$ daf i.e. with $\mathrm{t}$ hit $=$ 4,07 while from the student frequency distribution table at a significance level of $5 \%$ is known $\mathrm{t}_{\text {daf }}=\mathrm{t}_{(1-\alpha)(\mathrm{n} 1+\mathrm{n} 2-2)}=1,67$, while at the level of significance $1 \%$ is known $\mathrm{t}_{\text {daf }}=\mathrm{t}_{(1-\alpha)(\mathrm{n} 1+\mathrm{n} 2-2)}=2,34$, so Ho is rejected and $\mathrm{Ha}$ is accepted. This shows that the test results are quite meaningful and can accept the provisional assumption that there are differences in learning outcomes of students who apply the use of modules to those who do not use modules.

Based on the results of research that has been done it can be seen that the difference in the treatment of the use of teaching materials in this case with the use of modules has an effect on student learning outcomes. It is known that the use of modules in the teaching and learning process can improve student learning outcomes. So that it has a positive effect on student mathematics learning outcomes by using modules.

\section{CONLUSIONS AND SUGGESTIONS}

The conclusion is that the average mathematics learning outcomes of students who use modules are higher than the average mathematics learning outcomes of students who do not use modules. Thus the use of modules has a positive effect on mathematics learning outcomes in eighth grade students even semester MTs Hasanuddin Teluk Betung Bandar Lampung.

Based on these conclusions suggestions that can be useful for further researchers, teachers and schools, namely learning mathematics should be varied and not monotonous so that learning outcomes can be maximized, can improve the ability of teachers to compile modules and use these modules in their learning activities, so that the use of modules more effective in improving student learning outcomes then in their use must be adjusted to the characteristics of students, always motivating and rewarding the work of students, still providing assistance individually, still overseeing student activities.

\section{REFERENCES}

Abdurrahman, Saregar, A., \& Umam, R. (2018). Assessment Toward The Quantum Physics Concept Mastery of The Prospective Physics Teachers. Jurnal Pendidikan IPA Indonesia, 7(1), 34-40.

https://doi.org/10.15294/jpii.v6i2.7 239

Andayani, D. (2017). Penggunaan Modul E-Learning Sistem Reproduksi Manusia Untuk Meningkatkan Minat Siswa Dalam Mengoptimalkan Potensi Kecerdasan Majemuk. Jurnal Biotik, 5(2), 135.

Arslan, A. (2016). Effect of Jigsaw I technique on teaching Turkish grammar. 11(8), 635-641. https://doi.org/10.5897/ERR2016.2 709

Endah Retnowati, et al. (2018). Mathematics Problem Solving Skill Acquisition: Learning By Problem Posing Or By Problem Solving. Jurnal Cakrawala.

Erlinda, N. (2017). Peningkatan Aktivitas dan Hasil Belajar Siswa melalui Model Kooperatif Tipe Team Game Tournament pada Mata Pelajaran Fisika Kelas X di SMK Dharma Bakti Lubuk Alung. Tadris: Jurnal Keguruan Dan Ilmu Tarbiyah, 02(1), 49-55. https://doi.org/10.24042/tadris.v2i 1.1738

Fahrizal, P. I., \& Wiyanto, T. (2016). Penggunaan Modul Pembelajaran Berbasis Komputer (CAD) Untuk Meningkatkan Hasil Belajar Di SMK Negeri 3 Jombang. JPTM, 4(2), 86.

Haq, M. A., Najmonnisa, \& Saad, I. (2015). Impact of cooperative learning 
teaching methods on 7 th grade students' academic achievement: An experimental study. Journal of Elementary Education, 25(2), 89-112.

Jolliffe, I. T. (2002). Principal Component Analysis, Second Edition.

Komikesari, H. (2016). Peningkatan Keterampilan Proses Sains dan Hasil Belajar Fisika Siswa pada Model Pembelajaran Kooperatif Tipe Student Team Achievement Division. Jurnal Keguruan Dan Ilmu Tarbiyah, 1(1), 15-22.

Kristanto, V. H. (2017). Peningkatan Prestasi Belajar Matematika Melalui Penerapan Lesson Plan Berbasis Multiple Intelligence. Al-Jabar : Jurnal Pendidikan Matematika, 25-34. https://doi.org/10.2086/AJPM.5672

Kusuma, A. P. (2017). Implementasi Model Pembelajaran Student Teams Achievement Division (STAD) dan Team Assisted Individualization (TAI) ditinjau dari Kemampuan Spasial Siswa. Al-Jabar: Jurnal Pendidikan Matematika, 135-144.

Mallaherang, H., Arsyad, N., \& M, M. D. (2018). Efektivitas Penerapan Model Kooperatif Tipe NHT Dengan Pendekatan Auditory Intellectually Repetition Dalam Pembelajaran Matematika. Jutnal Vidya Karya, 33(2), 143.

Nurhayati, \& Boisandi. (2015). Penggunaan Modul Berbasis Konstruktivis pada Mata Kuliah Fisika Kuantum untuk Meningkatkan Penguasaan Konsep ditinjau dari Kemampuan Matematik Mahasiswa. Jurnal Penelitian \& Pengembangan Pendidikan Fisika, 1(2), 33-38.

Oktaviani, K. N., \& Retnowati, E. (2017). Faded-example as a Tool to Acquire and Automate Mathematics Knowledge Faded-example as a T ool to $\mathrm{A}$ cquire and $\mathrm{A}$ utomate $\mathrm{M}$ athematics $\mathrm{K}$ nowledge. Journal of Physics: Conference Series. https://doi.org/10.1088/17426596/755/1/011001

Putra, F. G. (2015). Eksperimentasi Model Pembelajaran Kooperatif Tipe Teams Games Tournament (TGT) Berbantuan Software Cabri 3d di Tinjau dari Kemampuan Koneksi Matematis Siswa Fredi Ganda Putra. Al-Jabar: Jurnal Pendidikan Matematika, 6(2), 143-153.

Rachmad, R., Ertikanto, C., \& Suana, W. (2017). Pengaruh Penggunaan Modul LCDS terhadap Hasil Belajar Kognitif dan Afektif. Jurnal Pembelajaran Fisika, 5(5), 33-43.

Retnowati, E., \& Ayres, P. (2018). Collaborative learning effects when students have complete or incomplete knowledge. Appl Cognit Psychol, (5), 681-692. https://doi.org/10.1002/acp.3444

Retnowati, E., Blegur, I. K. S., \& Retnowati, E. (2018). Designing worked examples for learning tangent lines to circles Designing worked examples for learning tangent lines to circles. Journal of Physics: Conference Series.

Santi Widyawati. (2016). Pengaruh Gaya Belajar Terhadap Prestasi Belajar Mahasiswa Program Studi Pendidikan Matematika (IAIM NU) Metro. Al-Jabar: Jurnal Pendidikan Matematika, 7(1), 107-114.

Setiawan, A. (2016). Hubungan Kausal Penalaran Matematis terhadap Prestasi Belajar Matematika pada Materi Bangun Ruang Sisi Datar ditinjau dari Motivasi Belajar Matematika Siswa. Al-Jabar: Jurnal Pendidikan Matematika, 7(1), 91100.

Simamora, F. G., Ertikanto, C., \& Wahyudi, I. (2017). Pengaruh Penggunaan Modul Pembelajaran Berbasis LCDS 
Desimal, 2 (3), 2019 - 240

Rika Rahmawati, Fitria Lestari, Rofiqul Umam

Terhadap Hasil Belajar Siswa. Jurnal Pembelajaran Fisika, 5(3), 91-101.

ST Aminah Kadang. (2017). Penggunaan Modul Fisika Scientific Approach Materi Fluida Statis Untuk Meningkatkan Kemampuan Kognitif Dan Komunikasi Ilmiah Siswa Kelas X MIA 5 SMAN 2 Kabupaten Sorong. Biolearning Journal, 8(2), 1-13.

Syed, A. A., Alvina, A., \& Amnda, A. (2017). Career Transition Program For Special Educational Needs Learning Disabilities Students. European Journal of Pharmaceutical and Medical Research, 4(11), 595-601.

Untari, E. (2017). Eksperimentasi Pembelajaran Kooperatif Tipe STAD Dan TPS Terhadap Prestasi Belajar Matematika Ditinjau Dari Motivasi Berprestasi. Al-Jabar: Jurnal Pendidikan Matematika, 35-42.

Wigati, A. A., Maharta, N., \& Suyatna, A. (2015). Pengaruh Penggunaan Modul Fisika Berbasis Inkuiri Terbimbing Terhadap Minat Dan Hasil Belajar. Jurnal Pembelajaran Fisika, 3(6), 12. 